\title{
Experimental and bioinformatic approaches for analyzing and visualizing cyanobacterial nitrogen and hydrogen metabolism
}

\author{
Röbbe Wünschiers* ${ }^{\#}$ \\ Institute for Genetics \\ University of Cologne \\ Germany \\ Tel: 4939482760112 \\ Fax: 4939482760199 \\ E-mail: robbe.wunschiers@uni-koeln.de \\ Rikard Axelsson \\ Swedenborgsgatan 41 C 75334 \\ Uppsala, Sweden \\ Tel: 46184891216 \\ Fax: 46184891022 \\ E-mail: r.axelsson@q-med.com \\ Martin Vellguth \\ Institute for Genetics \\ University of Cologne \\ Germany \\ Zülpicher Str. 47 \\ 50674 Cologne, Germany \\ Tel: 492214705661 \\ Fax: 492214705975 \\ E-mail: martin.vellguth@uni-koeln.de \\ Peter Lindblad \\ Department Photochemistry and Molecular Science \\ The Ångström Laboratories \\ Uppsala University \\ Box 523, 75120 Uppsala, Sweden \\ Tel: 46184712826 \\ Fax: 46184716844 \\ E-mail: peter.lindblad@fotomol.uu.se
}

Financial support: This work is part of the BMBF-funded Cologne University Bioinformatics Center (CUBIC) and was financially supported by grants to PL from the Swedish Research Council, the Swedish Energy Agency, and the EU/NEST Project SOLAR-H (contract 516510).

Keywords: bioinformatics, cyanobacteria, DNA-microarrays, gene expression, metabolic pathways, nitrogen availability, nitrogen fixation.

Present address: "SunGene GmbH \& Co KGaA, Correnstrasse 3, 06466 Gatersleben, Germany.

Abbreviations: ATP: adenosine 5'-triphosphate

BSA: bovine serum albumin

CAB: chlorophyll a/b-binding

ELIP: early light-induced proteins

GC: guanine/cytosine nucleotides

HLIP: high light-induced stress proteins

KEGG: Kyoto encyclopedia of genes and genomes

ORF: open reading frame

Many cyanobacteria are capable of utilizing light energy for nitrogen fixation. As a by-product of this nitrogenase mediated catalysis, hydrogen gas is produced. Several approaches to increase hydrogen production from cyanobacteria exist. Usually, these approaches are non-targeted. Here we exemplify how DNA-microarray based gene-expression analysis and bioinformatic visualization techniques can be used to analyze nitrogen and hydrogen metabolism from the filamentous, heterocyst forming cyanobacterium Nostoc PCC 7120. We analyzed the expression of 1249 genes from major metabolic categories under nitrogen fixing and non-nitrogen fixing growth. Of the selected genes, 494 show a more than 2-fold expression difference in the two conditions analyzed. Under nitrogen-fixing conditions 465 genes, mainly involved in energy metabolism, photosynthesis, respiration and nitrogenfixation, were found to be stronger expressed, whereas

*Corresponding author 
only 29 genes showed a stronger expression under nonnitrogen fixing conditions. To help understanding probe hybridization, all expression data were correlated with potential target secondary structures and probe GCcontent. For the first time the expression of high lightinduced stress proteins (HLIP-family) is shown to be linked to the nitrogen availability.

Cyanobacteria play an increasing in biotechnology (Singh et al. 2005). One potential but not yet feasible application is the photobiological production of hydrogen gas (Wünschiers and Lindblad, 2003; Dutta et al. 2005; Prince and Kheshgi, 2005). Cyanobacterial hydrogen metabolism is closely linked to dinitrogen assimilation in nitrogenfixation. All known nitrogenases evolve 1 to 7.5 mole hydrogen gas as they convert one mole dinitrogen to two mole ammonia. This apparent loss of energy is circumvented by uptake hydrogenases that allow the cyanobacteria to regain energy. Mutants which lack uptake hydrogenases and thus produce substantial amounts of hydrogen gas have successfully been engineered (Happe et al. 2000; Masukawa et al. 2002). The genetic and metabolic regulatory networking behind photobiological hydrogen production is only understood in fragments.

Heterocystous nitrogen-fixing cyanobacteria like Nostoc sp. strain PCC 7120 (Nostoc PCC 7120; formerly Anabaena PCC 7120) respond to the deprivation of combined nitrogen with morphological changes, i.e., the formation of heterocysts. These specialized non-dividing cells develop more or less equidistantly along the filaments with a ratio of about one heterocyst per 10 vegetative cells. In comparison to vegetative cells, the heterocyst is larger and more rounded. It provides an environment with low oxygen partial pressure since it lacks oxygen-evolving photosystem II activity and has a higher respiration rate (Böhme, 1998). Furthermore, it is surrounded by a thick glycolipidic cell wall that reduces the diffusion of oxygen. Heterocysts

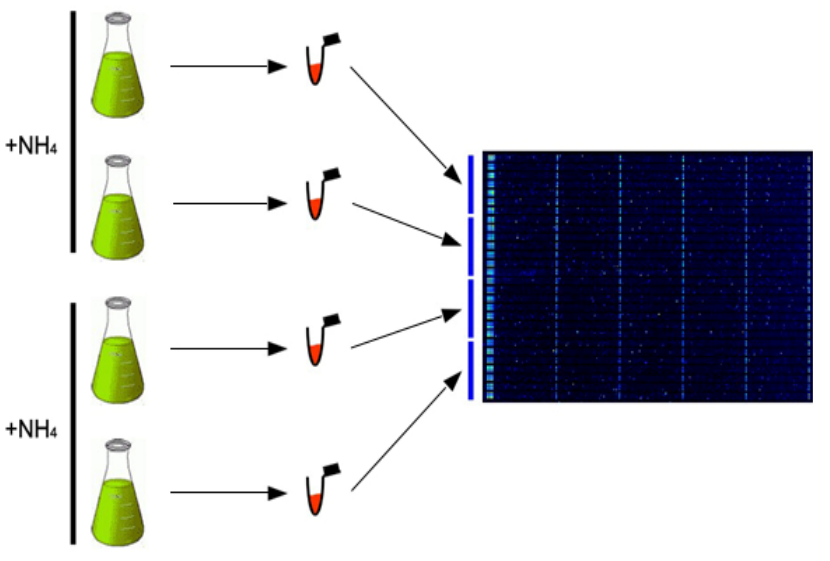

Figure 1. Experimental setup. Nostoc PCC 7120 batch cultures were grown under either nitrogen fixing $\left(-\mathrm{NH}_{4}\right)$ or non-nitrogen fixing conditions $\left(+\mathrm{NH}_{4}\right)$, harvested and subjected to total-RNA purification. After removal of rRNA by means of affinity chromatography, labeled and fragmented cRNA was hybridized to four individual arrays at single physical slides.

provide amino acids and receive carbohydrates from their neighboring vegetative cells. The differentiation process begins within a few hrs after combined-nitrogen deprivation, i.e. growth on dinitrogen as sole nitrogen source, and requires approximately $24 \mathrm{hrs}$ to complete. Single components involved in this process have been described (Golden and Yoon, 1998; Adams, 2000; Wolk, 2000; Meeks and Elhai, 2002; Herrero et al. 2004).

A key protein in heterocyst formation is NtcA (Herrero et al. 2001; Herrero et al. 2004), which is the global nitrogen regulator that controls, e.g., the expression of genes essential for heterocyst development such as the ABC-type transporter genes $\operatorname{dev} A B C$ and the regulator genes hetR and patS. Among many other factors that have been demonstrated to be important for heterocyst development are enzymes that are involved in the formation of

Table 1. Analyzed ORFs. Number of ORFs analyzed and present in each metabolic category of Nostoc PCC 7120.

\begin{tabular}{|c|l|c|}
\hline \multicolumn{2}{|c|}{ Metabolis class } & Number of ORFs analized \\
\hline A & Amino acid biosynthesis & 64 of $113(57 \%)$ \\
\hline B & Biosynthesis of cofactors, prosthetic groups and carriers & 14 of $152(9 \%)$ \\
\hline C & Cell envelope & 15 of $77(19 \%)$ \\
\hline D & Cellular processes & 47 of $96(49 \%)$ \\
\hline E & Central intermediary metabolism & 40 of $72(56 \%)$ \\
\hline F & DNA-replication, recombination, and repair & 29 of $105(28 \%)$ \\
\hline G & Energy metabolism & 20 of $100(20 \%)$ \\
\hline H & Fatty acid, phospholipid and sterol metabolism & 2 of $40(5 \%)$ \\
\hline I & Hypothetical & 567 of $3573(16 \%)$ \\
\hline J & Other categories & 204 of $678(30 \%)$ \\
\hline K & Photosynthesis and respiration & 98 of $157(62 \%)$ \\
\hline L & Purines, pirymidines, nucleosides and nucleotides & 2 of $58(3 \%)$ \\
\hline M & Regulatory functions & 36 of $360(10 \%)$ \\
\hline N & Transcription & 31 of $41(76 \%)$ \\
\hline O & Translation & 13 of $200(7 \%)$ \\
\hline P & Transport and binding proteins & 67 of $313(21 \%)$ \\
\hline Total & & 1249 of $6135(20 \%)$ \\
\hline
\end{tabular}


heterocyst-specific glycolipids and polysaccharides. The driving forces for these structural changes occurring during heterocyst formation are metabolic requirements: the dinitrogen fixing multi-enzyme complex nitrogenase requires a low oxygen partial pressure and a high supply of ATP and reduction equivalents (Dixon and Kahn, 2004). ATP may be generated by either cyclic photophosphorylation or oxidative phosphorylation while low-potential electrons may be generated from the degradation of carbohydrates produced during photosynthesis (Haselkorn and Buikema, 1992). Obviously, profound regulatory events coincide with growth on dinitrogen.

A powerful tool to study gene expression and its regulation is the DNA-microarray technique. Previously, we analyzed the expression of individual genes and operons of Nostoc spp. that are involved in nitrogen metabolism (Wünschiers and Lindblad, 2003). Here we describe an oligonucleotide based DNA-microarray expression analysis, where each gene is covered by up to 10 unique probes. Until now, only few oligonucleotide DNA-microarray based geneexpression analyses with heterocystous cyanobacteria have been reported (Ehira et al. 2005; Imashimizu et al. 2005; Ehira and Ohmori, 2006; Higo et al. 2006; Lechno-Yossef et al. 2006). Only two among these focus on the effect of nitrogen sources on gene expression. While Ehira and Ohmori (2006) follow the time course of nitrogen deprivation, ending at $24 \mathrm{hrs}$ after removal of anorganic nitrogen from growth medium, Lechno-Yossef et al. (2006) looked only at the expression differences after $14 \mathrm{hrs}$ of such a shift. In our experiment we look at the effect at continuous growth, i.e., fully shifted and equilibrated cultures.

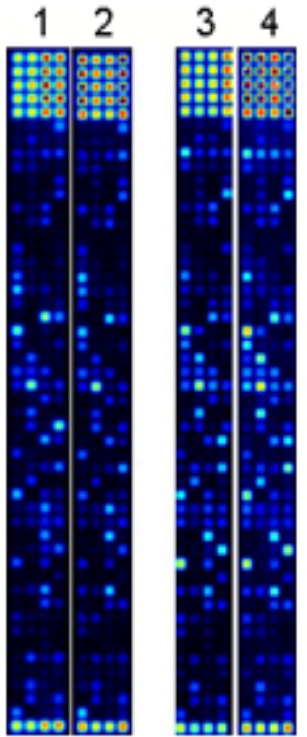

Figure 2. DNA-microarrays. Sections of four arrays used in the present analysis. The bright spots at the top and button of the arrays are controls used by the spot-finding software. (1) non-nitrogen fixing culture (2) non-nitrogen fixing culture, biological replicate (3) nitrogen fixing culture (4) nitrogen fixing culture, biological replicate.

Therefore we employed a novel, recently developed microarray technique where probe synthesis, hybridization, and signal detection take place in one device at strongly controlled physical conditions (Baum et al. 2003; Güimil et al. 2003). The expression data were used to (a) validate the technique employed and (b) obtain a global overview about the effect of growth on dinitrogen on Nostoc PCC 7120. For the latter, we set up a convenient data-processing

Table 2. Highly expressed ORFs under non-nitrogen fixing conditions. Annotated ORFs that show a more than 2-times higher expression level under non-nitrogen fixing than under nitrogen fixing conditions (the values are negative because nitrogen fixation was taken as reference). All ORFs annotated as putative, hypothetical, or unknown have been omitted. The key for metabolic classes can be found in Table 1.

\begin{tabular}{|c|c|c|c|c|c|}
\hline ORF & Class & Subclass & Annotation & Expr. diff. & p-value \\
\hline all0410 & (A) & Aromatic amino acid family & tryptophan sysnthase beta subunit TrpB & -2.0 & 0.02 \\
\hline alr7354 & (B) & Thioredoxin, glutaredoxin, and glutathione & glutathione S-transferase & -5.9 & 0.003 \\
\hline all0166 & $(\mathrm{E})$ & Polysaccharides and glycoproteins & alpha, alpha-trehalase & -6.9 & 0.003 \\
\hline asl0873 & (J) & Adaptation and atipical conditions & CAB/ELIP/HLIP superfamilty & -4.4 & 0.1 \\
\hline asr3042 & " & " & " & -11.3 & 0.08 \\
\hline asr3043 & $"$ & " & $"$ & -7.9 & 0.02 \\
\hline asl0449 & $"$ & $"$ & $"$ & -2.3 & 0.04 \\
\hline all0168 & " & Other & alpha-amylase & -9.5 & 0.001 \\
\hline all0275 & $"$ & $"$ & glycerophosphoryl diester phospodiesterase & -3.4 & 0.1 \\
\hline all0167 & $"$ & $"$ & maltooligosyltrehalose synthase & -2.3 & 0.02 \\
\hline all0875 & " & $"$ & probable alpha-glucanotransferase & -4.4 & 0.0005 \\
\hline all0412 & $"$ & " & putative zinc-binding oxidoreductase & -2.2 & 0.02 \\
\hline alr2405 & $(\mathrm{K})$ & Soluble electron carriers & flavodoxin & -7.6 & 0.003 \\
\hline all0258 & $"$ & " & plastocyanin precursor; PetE & -2.3 & 0.007 \\
\hline alr0702 & (O) & $\begin{array}{l}\text { Degradation of proteins, peptides, and } \\
\text { glycopeptides }\end{array}$ & serine proteinase & -2.8 & 0.002 \\
\hline all2674 & $(\mathrm{P})$ & Protein modification and translation factors & ferrichrome-iron receptor & -2.1 & 0.09 \\
\hline all0322 & $"$ & " & sulfate-binding protein SbpA & -4.0 & 0.006 \\
\hline
\end{tabular}


pipeline based on a MySQL database and a web-based graphical user interface. This front-end allows users to visualize gene-expression data on KEGG (Kyoto Encyclopedia of Genes and Genomes) pathway maps.

\section{MATERIALS AND METHODS}

\section{Strains and culture conditions}

The cyanobacterium Nostoc sp. strain PCC 7120 (formerly Anabaena sp. strain PCC 7120) was grown on either dinitrogen (nitrogen fixing) or combined nitrogen (nonnitrogen fixing) in batch cultures. Non-nitrogen fixing conditions were obtained by growing cells in BG1 $1_{0}$ (Stanier et al. 1971) supplemented with $5 \mathrm{mM} \mathrm{NH}_{4} \mathrm{Cl}$ and $10 \mathrm{mM}$ HEPES ( $\mathrm{pH}$ 7.5). Nitrogen-fixing conditions were obtained by growing cells in BG11 $1_{0}$. All cultures were grown in continuous white light (Thorn Polylux 4000 and Osram Warmton Warm Light 400 to $700 \mathrm{~nm} ; 40 \mu \mathrm{Em}^{-2} \mathrm{~s}^{-1}$ ) at $26^{\circ} \mathrm{C}$ with a magnetic stirrer being used to retain a homogeneous suspension. Cultures were harvested at midlogarithmic growth phase.

\section{RNA isolation}

Total RNA was extracted from $100 \mathrm{ml}$ cultures at $\mathrm{A}_{730 \mathrm{~nm}}=$ 0.5 . The cells were harvested by centrifugation at $6,000 \mathrm{xg}$ for $10 \mathrm{~min}$ together with $50 \mathrm{ml}$ crushed ice in a $250 \mathrm{ml}$ centrifuge bottle. The cell pellet was frozen in liquid nitrogen and thawed on ice. The cells were suspended in resuspension buffer $(0.3 \mathrm{M}$ sucrose, $10 \mathrm{mM}$ sodium acetate, $\mathrm{pH} 4.5)$, transferred to an Eppendorf tube and pelleted at $12,000 \mathrm{x} \mathrm{g}$ for $5 \mathrm{~min}$. The pellet was suspended in $250 \mu \mathrm{l}$ resuspension buffer with $75 \mu 1250 \mathrm{mM} \mathrm{Na}_{2}$-EDTA, and the suspension was incubated on ice for $5 \mathrm{~min}$. $375 \mu \mathrm{l}$ lysis

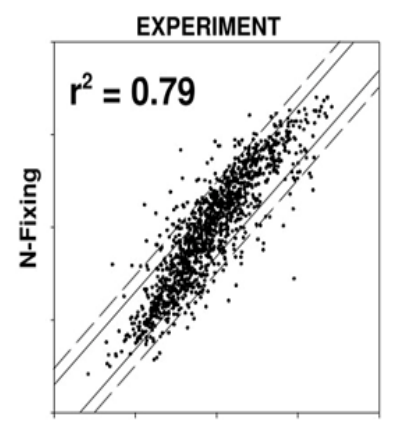

Non N-Fixing

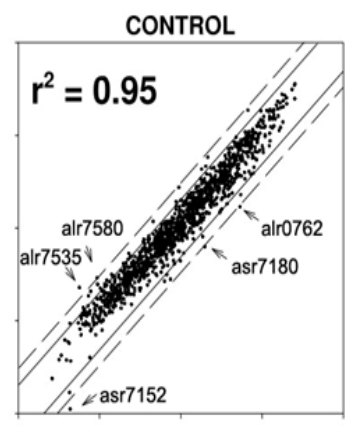

N-Fixing
Figure 3. Data quality. For the double-logarithmic plots nonnormalized raw data were used. The left plot shows the geneexpression differences between nitrogen fixing (ordinate) and nonnitrogen fixing, ammonia grown (abscissa) cultures of Nostoc PCC 7120. The right plot visualizes the gene-expression differences between two individual nitrogen fixing cultures. Significant outliers are marked by arrows. The straight and dashed lines represent 2and 3-fold expression differences, respectively. buffer $(2 \%(\mathrm{w} / \mathrm{v})$ SDS, $10 \mathrm{mM}$ Na-acetate, $\mathrm{pH} 4.5)$ was added, followed by incubation at $65^{\circ} \mathrm{C}$ for $3 \mathrm{~min} .700 \mu \mathrm{l}$ of $65^{\circ} \mathrm{C}$ phenol was added to the lysed cells, followed by incubation at $65^{\circ} \mathrm{C}$ for $3 \mathrm{~min}$ and then at $-70^{\circ} \mathrm{C}$ for $15 \mathrm{sec}$. The suspension was centrifuged at $12,000 \mathrm{x}$ g for $5 \mathrm{~min}$, the upper phase was collected and the hot phenol treatment was repeated twice, followed by an extraction with hot phenol:chloroform (1:1). 1/5 volume of $10 \mathrm{M} \mathrm{LiCl}$ and 2.5 volumes of $99.5 \%$ ethanol was added and the RNA was precipitated at $-20^{\circ} \mathrm{C}$ for $30 \mathrm{~min}$. The pellet was washed with $80 \%$ ethanol, suspended in water and stored in aliquots at $-70^{\circ} \mathrm{C}$. Quality and quantity of total RNA was analyzed with an Agilent 2100 Bioanalyser using the RNA 6000 Nano LabChip kit (Agilent Technologies, Boeblingen, Germany). If necessary, the RNA preparation was treated with 40 units of RNase-free DNase I (AmershamPharmacia Biotech, Uppsala, Sweden) according to the manufacturer's instructions. The average RNA yield per $100 \mathrm{ml}$ culture at $\mathrm{A}_{730 \mathrm{~nm}}=0.5$ was $50 \mu \mathrm{g}$.

\section{Preparation of biotin labeled, fragmented cRNA}

From $10 \mu \mathrm{g}$ of total RNA, low molecular weight RNA, e.g., tRNA and 5S rRNA, were removed by size exclusion chromatography (MEGAclear kit, Ambion). To remove $16 \mathrm{~S}$ and 23S rRNA, the MICROBExpress kit from Ambion was used. To increase the abundance of low expressed transcripts, the remaining RNA was linearly amplified by a modified Eberwine protocol (Eberwine et al. 1992) as follows. If not differently stated, all enzymes and chemicals were purchased from Invitrogene.

First strand synthesis. The pelleted RNA from the previous mRNA-enrichment steps was resuspended in 4.25 $\mu 1$ water and mixed with $1 \mu 1$ of T7 random hexamers $(0.5$ $\mu \mathrm{g} / \mu \mathrm{l}$; 5'-GGC CAG TGA ATT GTA ATA CGA CTC ACT ATA GGG AGG CGG NNN NNN-3'). Following incubation at $70^{\circ} \mathrm{C}$ for $10 \mathrm{~min}, 4^{\circ} \mathrm{C}$ for $2 \mathrm{~min}$ and $23^{\circ} \mathrm{C}$ for 5 min, $3.75 \mu 1$ reaction mix $(2 \mu \mathrm{l} 5 \mathrm{x}$ first strand synthesis buffer $(1 \mu \mathrm{l} 0.1 \mathrm{M}$ DTT, $0.5 \mu \mathrm{l} 10 \mathrm{mM}$ dNTP mix, $0.25 \mu \mathrm{l}$ 40 U RNase OUT) and 200 U Superscript II polymerase) was added to the RNA/primer mix. First strand synthesis reaction was performed with the following temperature scheme: $37^{\circ} \mathrm{C}$ for $20 \mathrm{~min}, 42^{\circ} \mathrm{C}$ for $20 \mathrm{~min}, 50^{\circ} \mathrm{C}$ for 15 $\min , 55^{\circ} \mathrm{C}$ for $10 \mathrm{~min}$ and $65^{\circ} \mathrm{C}$ for $15 \mathrm{~min}$. After adding 0.5 $\mu 1$ RNase $\mathrm{H}$ the reaction mix was incubated for another 30 $\min$ at $37^{\circ} \mathrm{C}$ and $2 \mathrm{~min}$ at $95^{\circ} \mathrm{C}$.

Second strand synthesis. The product of the first strand synthesis was mixed with $43.8 \mu \mathrm{l}$ water and $15 \mu \mathrm{l} 5 \mathrm{x}$ second strand synthesis buffer (20 U DNA-polymerase I, $1.5 \mu 110 \mathrm{mM}$ dNTP and $1 \mathrm{U}$ RnaseH) and incubated for 2 hrs at $16^{\circ} \mathrm{C}$. After addition of $10 \mathrm{U}$ T4 DNA-polymerase the reaction mix was first incubated at $16^{\circ} \mathrm{C}$ for $15 \mathrm{~min}$ and then at $70^{\circ} \mathrm{C}$ for $10 \mathrm{~min}$. 
Table 3. Photosynthesis and respiration. Highly expressed ORFs involved in photosynthesis or respiration. Expression levels are at least 30x above background (300).

\begin{tabular}{|c|c|c|c|c|c|}
\hline ORF & Submetabolism & Annotation & $+\mathbf{N}$ & $-\mathbf{N}$ & p-value \\
\hline all0138 & PS II & CP47 protein & 13326 & 9658 & 0.3 \\
\hline all0259 & PS II & cytochrome c550 & 9311 & 13906 & 0.4 \\
\hline asr3845 & PS II & cytochrome b559 alpha subunit & 12527 & 10674 & 0.3 \\
\hline asr3846 & PS II & cytochrome b559 beta subunit & 7606 & 10848 & 0.5 \\
\hline alr3421 & Cyt. b6/f & Plastoquinol plastocyanin reductase, cytochrome b6; PetB & 16697 & 12112 & 0.03 \\
\hline alr3422 & Cyt. b6/f & Plastoquinol plastocyanin reductase, aposytochrome subunit 4; PetD & 9381 & 13981 & 0.03 \\
\hline all0109 & PS I & Subunit III precursor; PsaF & 19723 & 23286 & 0.007 \\
\hline all0107 & PS I & Subunit XI; PsaL & 18416 & 25334 & 0.04 \\
\hline all4121 & Electron Carriers & ferredoxin-NADP $(+)$ reductase & 5205 & 12290 & 0.03 \\
\hline all4148 & Electron Carriers & ferredoxin I & 10984 & 14541 & 0.3 \\
\hline alr0021 & Phycobilisome & allophycocyanin alpha subunit; ApcA & 28417 & 24927 & 0.03 \\
\hline alr0022 & Phycobilisome & allophycocyanin beta subunit; ApcB & 25066 & 19930 & 0.2 \\
\hline alr0023 & Phycobilisome & core linker protein Lc7.8; ApcC & 13165 & 16575 & 0.2 \\
\hline alr0020 & Phycobilisome & core membrane linker protein; ApcE & 7285 & 18364 & 0.003 \\
\hline alr0529 & Phycobilisome & phycosyanin alpha chain; CpcA & 16927 & 18047 & 0.04 \\
\hline alr0528 & Phycobilisome & phycosyanin beta chain; $\mathrm{CpcB}$ & 20430 & 15579 & 0.4 \\
\hline alr0530 & Phycobilisome & phycosyanin associated rod linker protein CpcC & 13993 & 11404 & 0.1 \\
\hline alr0532 & Phycobilisome & phycocyanobilin Iyase alpha subunit; CpcE & 11497 & 18861 & 0.001 \\
\hline alr0524 & Phycobilisome & phycoerythrocyanin alpha chain; PecA & 11660 & 13985 & 0.2 \\
\hline alr0523 & Phycobilisome & phycoerythrocyanin beta chain; PecB & 22153 & 16828 & 0.1 \\
\hline alr0525 & Phycobilisome & phycoerythrocyanin associated rod linker protein PecC & 4337 & 12756 & 0.01 \\
\hline all1842 & $\mathrm{NADH}$ & $\mathrm{NADH}$ dehydrogenase & 2762 & 15611 & 0.004 \\
\hline all3840 & NADH & Chain J & 9877 & 14945 & 0.004 \\
\hline alr0225 & $\mathrm{NADH}$ & Subunit 6; NdhG & 8989 & 10480 & 0.002 \\
\hline alr0226 & $\mathrm{NADH}$ & Subunit 4L; NdhE & 9310 & 12526 & 0.004 \\
\hline alr3956 & NADH & Subunit 5 & 7635 & 12323 & 0.02 \\
\hline all0006 & ATP Synthase & Subunit delta; AtpD & 10175 & 10859 & 0.1 \\
\hline all0010 & ATP Synthase & Subunit a; Alpl & 15528 & 17750 & 0.03 \\
\hline all0011 & ATP Synthase & Subunit I; Atpl & 13805 & 13505 & 0.07 \\
\hline
\end{tabular}

Isolation of ds-cDNA. Double stranded cDNA was isolated from the product of second strand synthesis according to standard procedures (Maniatis et al. 1982).

In vitro transcription. The pelleted ds-cDNA was resuspended in $1.5 \mu 1$ water. The MEGAscript $\mathrm{T} 7 \mathrm{kit}$ (Ambion) was used for in vitro transcription. In addition to the standard nucleotides, $3.75 \mu \mathrm{l} 10 \mathrm{mM}$ Bio-16-CTP (NEN) and $3.75 \mu 175 \mathrm{mM}$ Bio-11-UTP (Roche) were added to the reaction mix. This led to the formation of biotinylated cRNA.

cRNA-isolation. The RNeasy kit (Qiagen) was applied for cRNA-isolation. All steps were performed according to the manufacturer's instructions.

cRNA-fragmentation. For cRNA-fragmentation $15 \mu \mathrm{g}$ cRNA was resuspended in $2.5 \mu 1$ water and $2.5 \mu 12 \mathrm{x}$ fragmentation buffer $(5 \mathrm{x}$ stock: $200 \mathrm{mM}$ Tris, $150 \mathrm{mM}$ Mg-acetate, $500 \mathrm{mM} \mathrm{K}$-acetate, $\mathrm{pH}$ 8.1). The reaction mix was incubated for $5 \mathrm{~min}$ at $94^{\circ} \mathrm{C}$. The fragmentation reaction was performed immediately prior to hybridization and checked by alkaline agarose electrophoresis.

\section{Oligonucleotide probe selection}

A unique Nostoc PCC 7120 probe set (as many 25-mer probes per open reading frame (ORF) as possible) was calculated based on the full genome sequence (retrieved online from CyanoBase: http://www.kazusa.or.jp/cyanobase/Anabaena/index.html) using a combination of sequence uniqueness criteria and rules for selection of oligonucleotides likely to hybridize with high specificity and sensitivity. The selection criteria were as described in Lockhart et al. (1996) with modifications for the longer probes used here (25-mers instead of 20-mers). If available, 10 unique probes per ORF were used in the experiments.

\section{DNA-microarray production and in situ oligonucleotide synthesis}

Light-activated in situ oligonucleotide synthesis was performed as described by Singh-Gasson et al. (1999) using a digital micromirror device, which is part of the geniom one device (febit biotech $\mathrm{GmbH}$, Heidelberg/Germany). The synthesis was performed within the geniom one device on an activated three-dimensional reaction carrier consisting of a glass-silica-glass sandwich (DNAprocessor). Four individually accessible microchannels (referred to as arrays), etched into the silica layer of the 
DNA-processor, were connected to the microfluidic system of the geniom device. Using standard DNA-synthesis reagents and 3'-phosphoramidites with a photolabile protecting group (Hasan et al. 1997; Beier and Hoheisel, 2000), oligonucleotides were synthesized in parallel in all four translucent arrays of one reaction carrier. Prior to synthesis, the glass surface was activated by coating with a silane-bound spacer.

\section{Hybridization}

Non-competitive hybridizations were performed with 7.5 $\mu \mathrm{g}$ fragmented cRNA (see above) in a final volume of 10 $\mu$ l. The hybridization solution contained $100 \mathrm{mM}$ MES ( $\mathrm{pH}$ 6.6), $0.9 \mathrm{M} \mathrm{NaCl}, 20 \mathrm{mM}$ EDTA, $0.01 \%$ (v/v) Tween 20 , $0.1 \mathrm{mg} / \mathrm{ml}$ sonicated herring sperm DNA, and $0.5 \mathrm{mg} / \mathrm{ml}$ BSA. RNA-samples were heated in the hybridization solution to $95^{\circ} \mathrm{C}$ for $3 \mathrm{~min}$ followed by $45^{\circ} \mathrm{C}$ for $3 \mathrm{~min}$ before being placed in an array which had been prehybridized for 15 min with $1 \%(\mathrm{w} / \mathrm{v})$ BSA in hybridization solution at room temperature. Hybridizations were carried out at $45^{\circ} \mathrm{C}$ for $16 \mathrm{hrs}$. After removing the hybridization solutions, arrays were first washed with nonstringent buffer $(0.005 \%(\mathrm{v} / \mathrm{v})$ Triton X-100 in 6 x SSPE) for $20 \mathrm{~min}$ at $25^{\circ} \mathrm{C}$ and subsequently with stringent buffer $(0.005 \%(\mathrm{v} / \mathrm{v})$ Triton X-100 in $0.5 \times \mathrm{SSPE})$ for $20 \mathrm{~min}$ at $45^{\circ} \mathrm{C}$. After washing, the hybridized RNA was fluorescence-stained by incubating with $10 \mu \mathrm{g} / \mathrm{ml}$ streptavidin-phycoerythrin and $2 \mu \mathrm{g} / \mu \mathrm{lBSA}$ in $6 \mathrm{x}$ SSPE at 25 for $1^{\circ} \mathrm{C} 5 \mathrm{~min}$. Unbound streptavidin-phycoerythrin was removed by washing with non-stringent buffer for $20 \mathrm{~min}$ at $25^{\circ} \mathrm{C}$. Two biological replicates of each condition have been hybridized.

\section{Detection and data processing}

The CCD-camera based fluorescence detection system, equipped with a $\mathrm{Cy} 3$ filter set, integrated into the geniom one automate was used. 36 pixels per spot were available for data analysis. Processing of raw data, including background correction, array to array normalization and determination of gene-expression levels, as well as calculation of expression differences were performed as described before (Zhou and Abagyan, 2002). All steps were carried out using the PROP-algorithm of the geniom application software which is based on the MOIDalgorithm described by Zhou and Abagyan (2002). Background correction is based on probes with no corresponding mRNA-target and the average of the lowest $5 \%$ expressed genes. Data normalization is based on iteratively correcting the raw data on these genes. Significance levels for differentially expressed ORFs have been calculated using a two-sided t-test.

\section{Probe secondary structure and GC-content analysis}

In order to correlate probe secondary structures and GCcontents with their expression value, the secondary
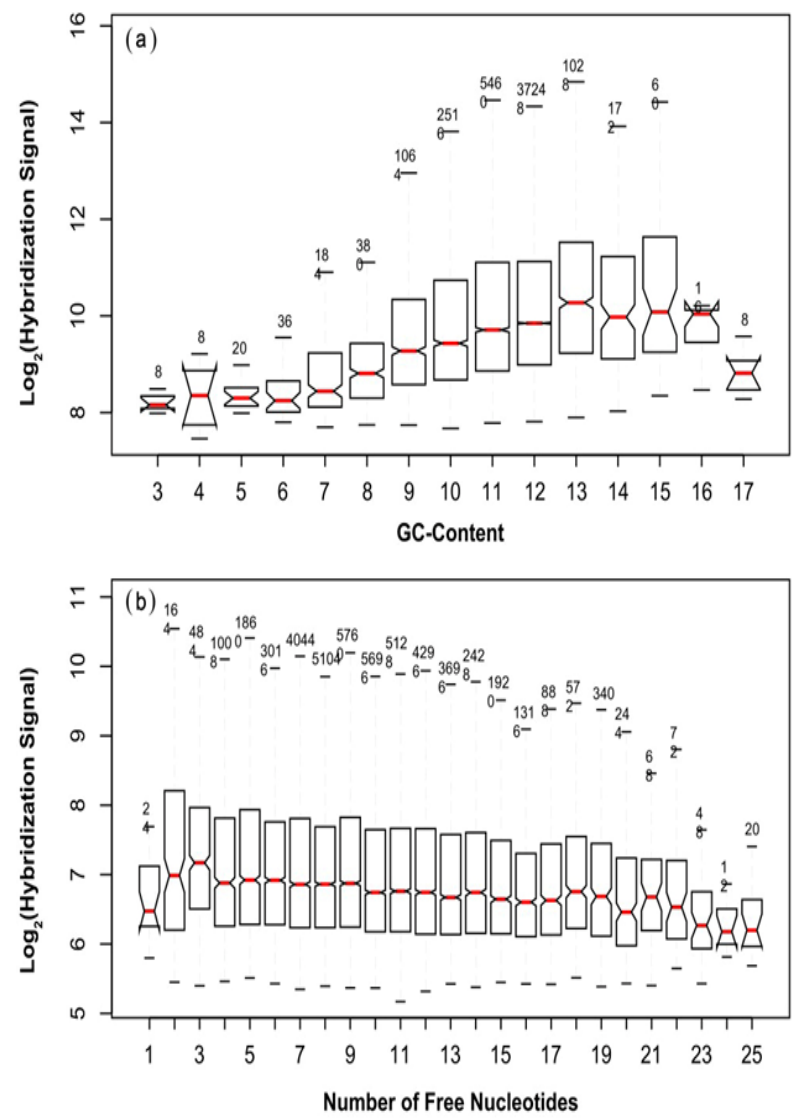

Figure 4. Hybridization effects. The notches around the medians in both box plots ( $a$ and $b$ ) indicate the 95\% confidence interval that the median from one box differs from the median of another box, i.e., if the notches do not overlap the corresponding medians are significantly different. The upper and lower box indicate the second and third quartile, respectively. The plot whiskers extending out from the box to the extreme values. The number above the upper whisker state the number of observations for the corresponding box.

(a) The logarithmized intensity of the hybridization signal is plotted against the GC-content of the 25 -mere probe sequence 1.

(b)The logarithmized intensity of the hybridization signal is plotted against the number free secondary structure features (bulges and loops) in the target sequence.

structure of each ORF was calculated using the Vienna RNA Package Version 1.4 (Hofacker et al. 1994). The probes were aligned to their corresponding ORF and the potential probe structure extracted. The number of hybridized (stem duplexes) versus free (loops and bulges) probe nucleotides as well as the probe's GC-content were used in further analysis.

\section{HyDaBa database}

All gene-expression data obtained are saved in the Hydrogenase Database (HyDaBa). This relational database allows cross-linking of the expression data with the annotated genome data from NCBI and Cyanobase and pathway maps available from KEGG. The latter is achieved in real-time via a SOAP-interface. HyDaBa is based on a Apache Webserver, MySQL database and a front-end 
Table 4. Heterocysts. ORFs included in the present study that are specific to heterocysts and show significant expression differences. Expr.: expression difference between non-nitrogen and nitrogen fixing condition.

\begin{tabular}{|c|l|c|c|}
\hline ORF & \multicolumn{1}{|c}{ Description } & Expr. & p-value \\
\hline all0521 & two-component response regulator, heterocyst pattern formation protein PatA & 2.4 & 0.09 \\
\hline all0813 & heterocyst-specific glycolipids-directing protein HglK & 4.6 & 0.001 \\
\hline all1430 & heterocyst ferredoxin; FdxH & 12.9 & 0.01 \\
\hline all1431 & HesB protein & 9.7 & 0.03 \\
\hline all1432 & HesA protein & 8.6 & 0.01 \\
\hline all1730 & similar to HetF protein & 3.4 & 0.01 \\
\hline all2512 & transcriptional regulator; PatB & 2.5 & 0.06 \\
\hline all5346 & heterocyst specific ABC-transporter, membrane spanning subunit DevC homolog & 8.9 & 0.4 \\
\hline all5347 & heterocyst specific ABC-transporter, membrane fusion protein DevB homolog & 3.0 & 0.007 \\
\hline alr1603 & putative heterocyst to vegetative cell conection protein (fraH) & 2.4 & 0.07 \\
\hline alr2339 & heterocyst differentiation protein HetR & 2.1 & 0.02 \\
\hline alr2817 & heterocyst differentiation protein HetC & 5.8 & 0.009 \\
\hline alr2818 & heterocyst differentiation protein HetP & 2.6 & 0.03 \\
\hline alr2834 & glycosyltransferase; hepC & 18.5 & 0.2 \\
\hline alr2835 & heterocyst specific ABC-transporter hepA & 5.7 & 0.01 \\
\hline alr3234 & similar to heterocyst formation protein HetP & 6.6 & 0.2 \\
\hline alr3648 & heterocyst specific ABC-transporter, membrane spanning subunit DevC homolog & 2.7 & 0.1 \\
\hline alr3649 & heterocyst specific ABC-transporter, ATP-binding subunit DevA homolog & 3.7 & 0.1 \\
\hline alr3698 & heterocyst envelope polysaccharide sysnthesis protein HepB & 6.5 & 0.08 \\
\hline alr3710 & heterocyst specific ABC-transporter, membrane fusion protein DevB & 3.3 & 0.2 \\
\hline alr3711 & heterocyst specific ABC-transporter, membrane spanning subunit DevC & 12.4 & 0.002 \\
\hline alr3712 & heterocyst specific ABC-transporter, ATP-binding subunit DevA & 13.1 & 0.005 \\
\hline alr4281 & heterocyst specific ABC-transporter, membrane spanning subunit DevC homolog & 3.5 & 0.1 \\
\hline alr4812 & heterocyst differentiation related protein PatN & 2.3 & 0.03 \\
\hline alr5355 & heterocyst glycolipid synthase; HglC & 4.1 & 0.03 \\
\hline alr5358 & ketoacyl reductase; HetN & 4.0 & 0.05 \\
\hline
\end{tabular}

programmed in PHP. All data are publicly accessible via this web interface that can be accessed using "guest" and "hydaba06" as user name and password, respectively.

\section{RESULTS AND DISCUSSION}

In the present study we analyzed the expression of 1249 selected genes from 16 metabolic categories (ca. $20 \%$ of the complete genome) of Nostoc PCC 7120 cultures under nitrogen fixing and non-nitrogen fixing conditions (Table 1). Therefore we applied a DNA-microarray based approach (Figure 1).

\section{Preparation of the DNA-processor}

Oligonucleotide synthesis, hybridization with target cRNA, and signal detection were performed with one single device, named geniom one (febit biotech $\mathrm{GmbH}$, Heidelberg/Germany, Baum et al. (2003)). 25-mer oligonucleotide probes were synthesized in situ on the DNA-microarray surface. In order to obtain a broad picture of gene-expression differences between nitrogen fixing and non-nitrogen fixing Nostoc PCC 7120 cultures, 500 manually and 749 randomly selected target genes from all major metabolic categories were analyzed (Table 1; Kaneko et al. (2001)). This selection was based on the genome sequence and annotation available from the CyanoBase consortium. In order to ensure reproducibility of the microarray analysis, up to 10 unique 25 -mer oligonucleotide probes per target ORF were distributed randomly over the DNA-processor. Due to their small size, 132 ORFs were represented by fewer than 10 unique probes. Of theses, 78 represent unknown and 15 hypothetical proteins, respectively. Of the remaining only 5 ORFs were represented by less than 4 unique probes.

\section{General data analysis}

Figure 2 shows a section of four arrays used in this analysis. Due to in situ probe synthesis with a digital micromirror device both the spot morphology and topology are extremely homogeneous. The use of one physical surface for all arrays and the fixed placement of the slide during all processing steps results in very low experimental variation. In order to visualize the signal-to-noise ratio the fluorescence-intensity ratio of either two RNA-samples from different growth conditions or from two RNAsamples from the same growth condition are plotted in double-logarithmic scales (Figure 3). It can be clearly seen that the comparison of two different metabolic states scatters much broader than the self-to-self comparison. The variance of the data is displayed by their respective Pearson correlation value r. Five ORFs in the self-to-self comparison show an unexpectedly large variation. In three cases (asr7152, alr7535 and alr7580) this can be explained 

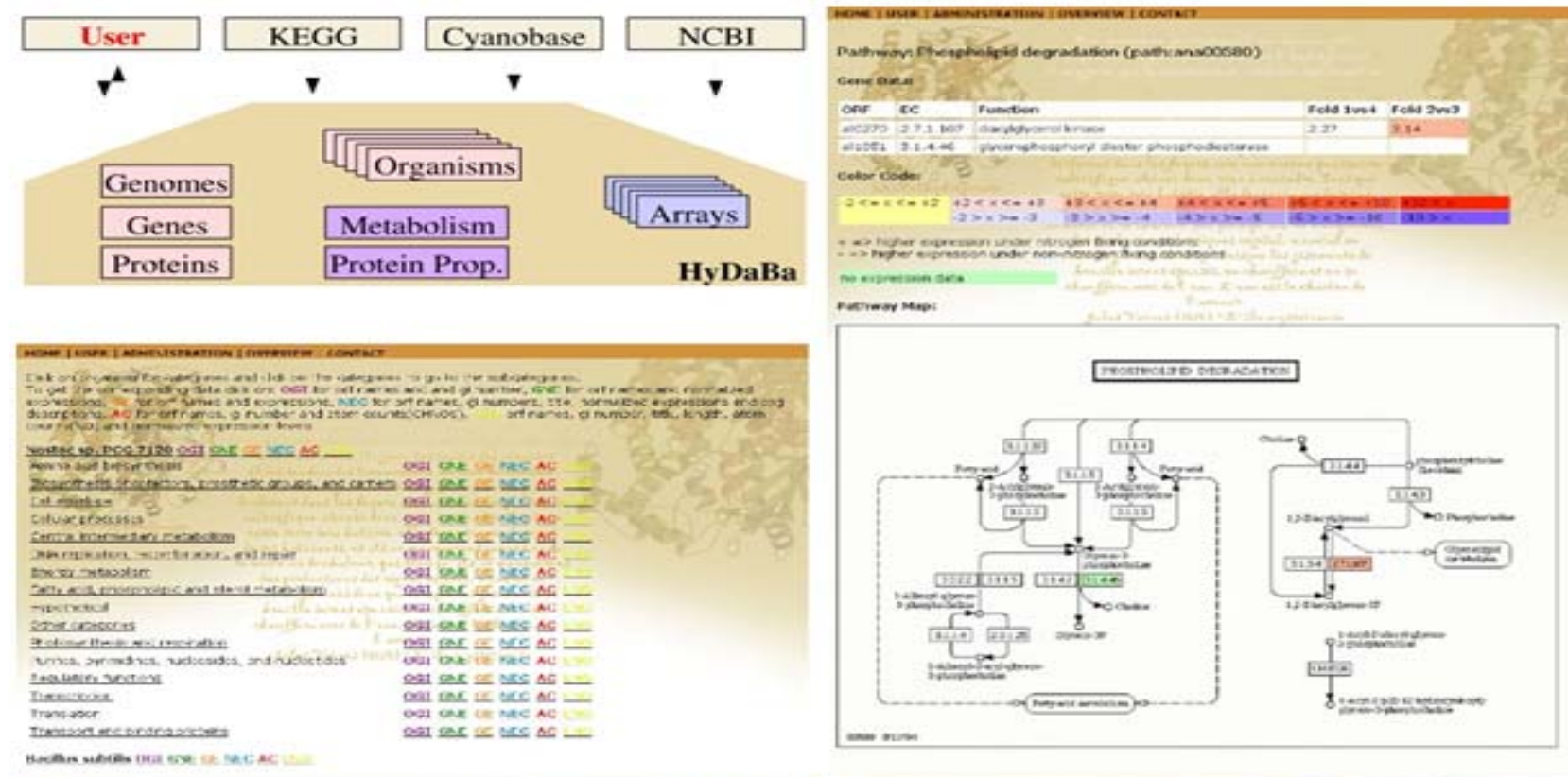

Figure 5. HyDaBa database. All experimental gene-expression data are saved in a relational database (http://www.hydaba.unikoeln.de). This database allows cross-linking of the gene-expression data with genome data from NCBI and Cyanobase and metabolic charts available from KEGG. HyDaBa is based on a Apache Webserver, a MySQL database and a front-end programmed in PHP. All data are publicly accessible via this web interface. Upper left: database outline; Lower left: screen shot of metabolic categories; Right: screen shot of expression data overlayed on metabolic charts.

by their low, close to threshold fluorescence-signal intensity.

\section{GC-content and probe secondary structure analysis}

It is often observed in oligonucleotide-based DNAmicroarray experiments that probes directed against one single transcript show large hybridization level variations. The reason for this fluctuation remains still unknown and is one major reason for the necessity to calculate the expression value for each transcript from several unique probes (Kuo et al. 2002; Pozhitkov et al. 2006). We analyzed the influence of both GC-content and secondary structure formations on the hybridization signal.

Figure $4 \mathrm{a}$ shows the correlation between the number of guanine and cytosine nucleotides (GC-content) in the 25mere probes and the corresponding hybridization signal. There is no probe with less than 3 or more than 17 GCs. In the range between 7 and 13 GCs there is a clear linear correlation between GC-content and hybridization signals. To many (more than 50\%) or to few (less than $25 \%$ ) GCs in the probe result in non-linear behavior. As can be seen from the number of observations given in the plot, less than $0.7 \%$ (328 out of 48208) of all unique probes are affected by this non-linear behavior. At the current stage it is not possible to draw conclusions from the extremes on both sides of Figure 4a because they are only represented by few data. In contrary to the GC-content, the predicted secondary structure (stems, loops and bulges) of the transcript has only little influence on the hybridization signal (Figure 4b). This was expected because (a) the target was chopped into smaller fragments prior to hybridization, and (b) the hybridization conditions are set such that no secondary structures should form in either the probe or the target.

The effect of individual probe hybridization signals is usually ignored in oligonucleotide-based DNA-microarray experiments. Instead, the average over all probes is used for each transcript. However, these effects have to be taken into account if only few probes are available for particular transcripts. Furthermore, we can conclude that a large portion of the hybridization signal variation is intrinsic to the probe sequence and can not be explained by currently known DNA-duplex formation physico-chemistry.

\section{Data processing and visualization}

DNA-microarray experiments involve accumulation and management of large amounts of data. Apart from the experimental data, information from open access knowledge databases and sequence analysis are collected. To provide optimal accessibility to all data we set up a MySQL database on an Apache driven Internet server. The database holds both raw and processed data. Besides data management the database allows cross-connectivity of expression data with annotations from NCBI database, Cyanobase and KEGG (Figure 5) In order to access and query the database (which has been coined HyDaBa) a PHP-based and Internet-accessible front-end has been developed. This front-end helps to query the data, guides 
Table 5. Respiratory terminal oxidases. Expression differences for respiratory terminal oxidases under nitrogen fixing conditions.

\begin{tabular}{|l|c|c|c|}
\hline \multicolumn{1}{|c|}{ ORF } & Description & Expr. & p-value \\
\hline COX 1 & \multicolumn{1}{|c|}{} \\
\hline alr0950 & cytochrome c oxidase subunit II (coxB) & less than \pm 2 & 0.2 \\
\hline alr0951 & cytochrome c oxidase subunit I (coxA) & less than \pm 2 & 0.04 \\
\hline alr0952 & cytochrome c oxidase subunit III (coxC) & less than \pm 2 & 0.01 \\
\hline COX 2 & 4.0 & 0.07 \\
\hline alr2514 & cytochrome c oxidase subunit II (coxB) & 7.0 & 0.03 \\
\hline alr2515 & cytochrome c oxidase subunit I (coxA) & 31.8 & 0.002 \\
\hline alr2516 & cytochrome c oxidase subunit III (coxC) & \\
\hline COX 3 & cytochrome c oxidase subunit II (coxB) & less than \pm 2 & 0.7 \\
\hline alr2731 & cytochrome c oxidase subunit I (coxA) & 3.3 & 0.02 \\
\hline alr2732 & cytochrome c oxidase subunit III (coxC) & 4.7 & 0.04 \\
\hline alr2734
\end{tabular}

the user to define and store new queries, allows data up-and download, and can be easily extended due to its modular setup with template pages. The most important feature of $\mathrm{HyDaBa}$ constitutes the mapping of gene-expression data onto metabolic charts from the KEGG database (Figure 5). Technically, this has been achieved by using a SOAP interface (Kawashima et al. 2003). Equally important is the possibility to query for all data available for a given ORF. $\mathrm{HyDaBa}$ can be accessed at http://www.hydaba.unikoeln.de/ using "guest" and "hydaba06" as user name and password, respectively.

\section{Global differences in gene expression upon growth on dinitrogen}

Growth on dinitrogen as sole nitrogen source acts like a positive transcriptional switch in Nostoc PCC 7120. There is a much larger fraction of genes stronger expressed under nitrogen fixing than under non-nitrogen fixing conditions and only a minority of genes shows a decreased expression level. Only 17 annotated and 12 hypothetical ORFs exhibit a significantly higher expression under non-nitrogen fixing conditions (Table 2) whereas 281 annotated and 184 hypothetical ORFs are more strongly expressed under nitrogen fixing conditions. In Figure 6, these geneexpression differences are clustered according to the participation of the corresponding ORF in specific metabolic categories. The strongest expressed genes participate in photosynthesis and respiration (K). Closer analysis reveals that 21 of the 29 strongest expressed genes in this group belong to photosynthesis, 11 of which are structural proteins of phycobilisomes (Table 3). These findings clearly illustrate the extensive energy demand for nitrogen fixation. The cell expands its light harvesting complexes in order to direct more light energy to the photosystems and produce both more ATP and NADPH. The stronger expression of proteins involved in respiration underlines previous findings that the respiration rate is increased under nitrogen fixing conditions in cyanobacteria (Murry and Wolk, 1989). It is believed that this process supports the removal of oxygen which otherwise would inactivate the nitrogenase enzyme complex (Fay, 1992).

\section{Heterocyst-related genes}

As a key global regulator, NtcA plays an important role in the expression of many genes involved in heterocyst differentiation and nitrogen assimilation. For the unicellular, non-differentiating cyanobacterium Synechococcus PCC 7942 it has been shown that the binding affinity of NtcA to its target DNA-sequence is elevated by 2-oxoglutarate (Vázquez-Bermúdez et al. 2002; Vázquez-Bermúdez et al. 2003). Thus, 2-oxoglutarate exerts a direct role on NtcA-mediated transcription activation. Furthermore, it plays a central role in sensing the nitrogen status, or rather the $\mathrm{C} / \mathrm{N}$-balance. Although synthesized in the heterocyt, 2-oxoglutarate cannot serve as

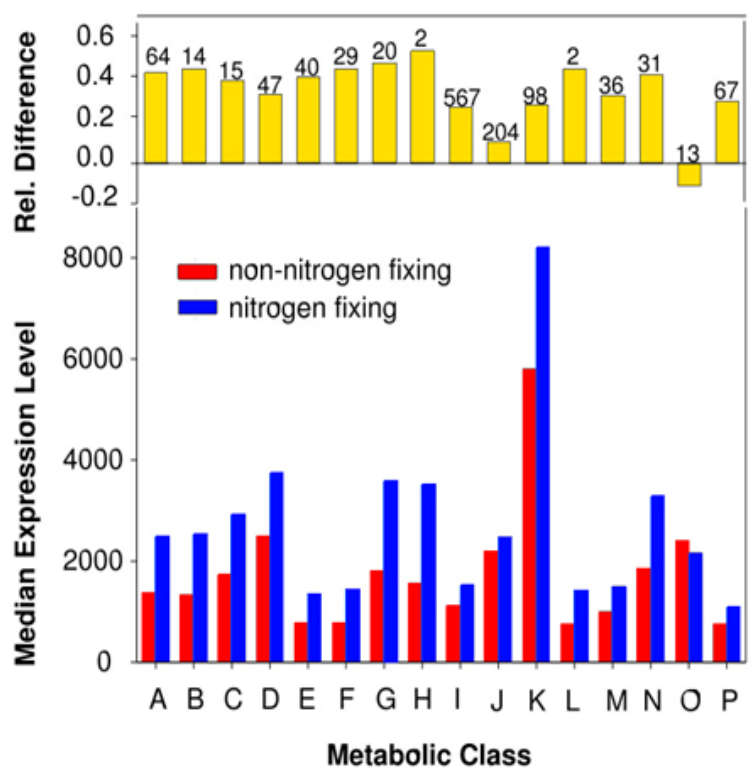

Figure 6. Global expression differences. Measured geneexpression differences in major metabolic categories. The lower plot shows the median expression level of the analyzed ORFs in the corresponding metabolic class. The upper plot shows the corresponding relative change (maximum range: -1 to 1 ). The numbers above the bars represent the number of ORFs analyzed in the corresponding category. The legend to the letters denoting metabolic classes can be found in Table 1 . 
a substrate for glutamate synthesis in heterocysts because the necessary ferredoxin glutamine 2-oxoglutarate amidotransferase is not expressed in heterocysts (MartínFigueroa et al. 2000). This conversion is done in the vegetative cells. Thus, glutamate is imported, while 2oxoglutarate and glutamine are exported to vegetative cells (Figure 7). We found key enzymes catalyzing the synthesis of 2-oxoglutarate, aconitase hydratase (2.8-times; EC 4.2.1.3) and isocitrate dehydrogenase (4.7-times; EC 1.1.1.42), respectively, being stronger expressed under nitrogen fixing condition (Figure 7). The hetC gene (alr2817), which encodes a putative ABC-transporter that is essential for heterocyst formation, has been shown to be a direct target of the transcriptional regulator NtcA (MuroPastor et al. 1999). Indeed we see a 5.8-time stronger expression under nitrogen fixing conditions. Table 4 shows expression differences for all known ORFs involved in heterocyst formation included in this study.

\section{Nitrogen metabolism-related genes}

The conversion of dinitrogen to ammonia, catalyzed by the nitrogenase enzyme complex, is only the first step in a series of reactions that make nitrogen available to the cell. The nitrogenase enzyme complex provides two products that are metabolized, hydrogen gas and ammonia, respectively. The former is taken up by an uptake hydrogenase while the latter is incorporated to glutamate by the glutamine synthase yielding glutamine. Figure 7 gives an overview over the main pathways and enzyme complexes involved in nitrogen fixation. The nitrogenase consists of three subunits, the molybdenum-iron protein alpha chain (NifD, all1454), the molybdenum-iron protein beta chain (NifK, all1440), and the iron protein (NifH, all1455). We found nifK and nifH to be more than 10-times more strongly expressed under nitrogen fixing conditions. One ORF (nifH2, alr0874) of yet unknown function that is paralogous (92\% similarity, $86 \%$ identity) to the iron protein (nifH, all1455) was found to be expressed at a very lower level and is only slightly stronger expressed under nitrogen fixing conditions (Figure 7). Thus, the gene product of nifH2 is probably not involved in the nitrogen fixation reaction. The glutamine synthase (glutamateammonia ligase) is encoded by $g \ln A$ (alr2328). Northern blot studies in Nostoc PCC 7120 have shown that the $g \ln A$ transcript is present in both nitrogen-fixing as well as nonnitrogen fixing cultures, but more abundant in the latter
(Orr and Haselkorn, 1982). This is in accordance with our results.

\section{Other genes}

Phycobilisomes. Phycobilisomes are the major lightharvesting complexes of cyanobacteria. These are multiprotein assemblies that are functionally associated with photosystem II and constitute up to $50 \%$ of the total cellular protein. It has been shown previously that phycobilisomes serve as a nitrogen storage. Upon nitrogen starvation they can be completely degraded within two days. Phycobilisome degradation is thought to provide substrates for protein biosynthesis. As discussed above, we observed strong expression of major components involved in photosynthesis under nitrogen fixing conditions. Accordingly, all proteins included in this analysis and that constitute phycobilisomes are around 3-times more strongly expressed under nitrogen-fixing conditions.

Respiratory terminal oxidases. Nostoc PCC 7120 possesses three cytochrome c oxidase gene clusters, cox1 (alr0950, alr0951, alr0952), cox2 (alr2514, alr2515, alr2516), and cox3 (alr2729, alr2730, alr2731, alr2732, alr2734), respectively (Valladares et al. 2003). While cox1 and cox2 are homologous to aa-type cytochrome c oxidases (Schmetterer, 1994; Jones and Haselkorn, 2002), cox3 is most similar to alternative respiratory terminal oxidases (Valladares et al. 2003). The expression of $\operatorname{cox} 2$ and cox 3 has been reported to be restricted to heterocysts (Valladares et al. 2003). In accordance to this result we see no difference in the expression of cox 1 , while cox 2 and $\operatorname{cox} 3$ are more strongly expressed under nitrogen fixing conditions (Table 5).

Adaptations and atypical conditions. One group of genes, members of which are up to 11-times more strongly expressed under non-nitrogen fixing conditions belong to the high light-induced proteins (HLIP-family; Table 6) (Montané and Kloppstech, 2000; Heddad and Adamska, 2002). These proteins belong to the CAB/ELIP/HLIPsuperfamily and are evolutionary related to each other (Heddad and Adamska, 2002). While CAB (chlorophyll a/b-binding) proteins are major constitutions of the light harvesting complexes, ELIPs (early light-induced proteins) and HLIPs are taking over photo-protective functions. The HLIP-family in pro-and eukaryotic photosynthetic

Table 6. HLIP-family. Expression differences for the HLIP-family involved in adaptations and atypical conditions. Negative values indicate stronger expression under non-nitrogen fixing conditions.

\begin{tabular}{|c|l|c|c|}
\hline ORF & \multicolumn{1}{|c|}{ Description } & Expr.-diff & p-value \\
\hline asl0449 & CAB/ELIP/HLIP-related protein & -2.3 & 0.04 \\
\hline asl0514 & CAB/ELIP/HLIP-superfamily & less than \pm 2 & 0.3 \\
\hline asl0873 & CAB/ELIP/HLIP-superfamily & -4.4 & 0.2 \\
\hline asl2354 & CAB/ELIP/HLIP-related protein & less than \pm 2 & 0.5 \\
\hline asr3042 & CAB/ELIP/HLIP-superfamily of proteins & -11.3 & 0.09 \\
\hline asr3043 & CAB/ELIP/HLIP-superfamily of proteins & -7.9 & 0.02 \\
\hline asl3726 & CAB/ELIP/HLIP-superfamily & less than \pm 2 & 0.2 \\
\hline asr5262 & CAB/ELIP/HLIP-superfamily of proteins & less than \pm 2 & 0.05 \\
\hline
\end{tabular}


organisms consists of more than 100 different stress proteins which have one membrane spanning alpha helix. They accumulate only transiently in photosynthetic membranes in response to light stress and have photoprotective functions. At the amino acid level, members of the HLIP-family are closely related to lightharvesting $\mathrm{CAB}$ antenna proteins of photosystem I and II, present in higher plants and some algae. Despite this similarity it is believed that HLIP-proteins fulfill their photoprotective role by either transient binding of free chlorophyll molecules or by participating in energy dissipation (Montané and Kloppstech, 2000). Photooxidative stress in not necessarily connected to high light fluxes but can also be caused by nutrient deprivation that ultimately lead to oversaturation of the photosynthetic electron transport chain. At this point one can only speculate why the HLIP-family is stronger expressed under non-nitrogen fixing conditions. Since the same light and temperature settings were employed for both growing conditions, one argument would be that more light is required (and thus "consumed") under nitrogen fixing conditions. Indeed the nitrogenase enzyme complex has immense energy and reducing power demands. In concert with the higher availability of nitrogen upon growth on

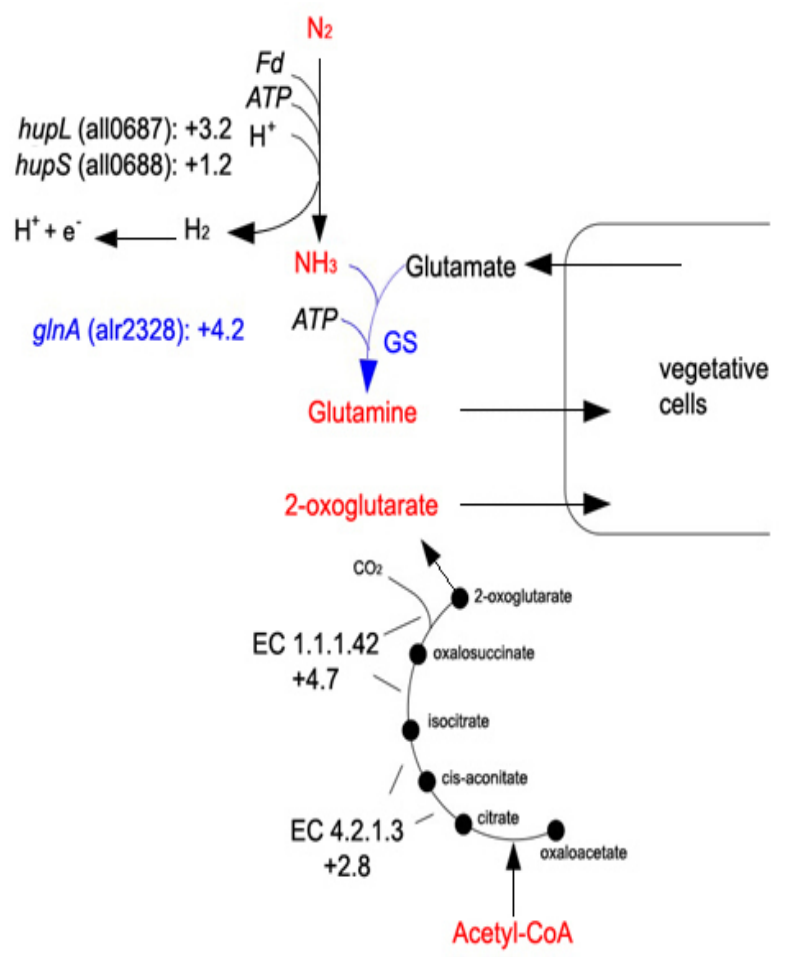

Figure 7. Nitrogen metabolism in Anabaena PCC 7120 heterocysts. The main components involved in nitrogen fixation and assimilation include nitrogenase (nif-genes) and glutamine synthase (GS, glnA). 2-oxoglutarate is synthezised from oxaloacetate and acetyl-CoA by the incomplete TCA-cycle, of which the aconitate hydratase (EC 4.2.1.3) and isocitrate dehydrogenase (EC 1.1.1.42) are shown. Together with glutamine, 2-oxoglutarate is exported to vegetative cells while glutamate is imported. dinitrogen (see above) we conclude that this growth condition frees Nostoc PCC 7120 from stress. To our knowledge this is the first report about differential expression of members of the HLIP-family in cyanobacteria upon combined-nitrogen deprivation. Analysis of the location of the HLIP-family members shown in Table 6 reveals no link to known ORFs that are involved in nitrogen metabolism. Only as10449 is located immediately downstream of the allophycocyanin alpha subunit (apcA, all0450) and thus demonstrates its potential functional relation to photosynthesis. Future work might help to uncover the function of these proteins in pro-and eukaroytes.

\section{ACKNOWLEDGMENTS}

The authors like to thank Dr. M. Baum and N. Rittner from febit for technical assistance with the microarray experiments and H. Eckes for initial work on the database front-end. R.W. likes to thank Prof. D. Tautz for his continuous support.

\section{REFERENCES}

ADAMS, David G. Heterocyst formation in cyanobacteria. Current Opinion in Microbiology, December 2000, vol. 3, no. 6, p. 618-624.

BAUM, Michael; BIELAU, Simone; RITTNER, Nicole; SCHMID, Kathrin; EGGELBUSCH, Kathrin; DAHMS, Michael; SCHLAUERSBACH, Andrea; TAHEDL, Harald; BEIER, Markus; GÜIMIL, Ramon; SCHEFFLER, Matthias; HERMANN, Carsten; FUNK, Jörg-Michael; WIXMERTEN, Anke; REBSCHER, Hans; HÖNIG, Matthias; ANDREAE, Claas; BÜCHNER, Daniel; MOSCHEL, Erich; GLATHE, Andreas; JÄGER, Evelyn; THOM, Marc; GREIL, Andreas; BESTVATER, Felix; OBERMEIER, Frank; BURGMAIER, Josef; THOME, Klaus; WEICHERT, Sigrid; HEIN, Silke; BINNEWIES, Tim; FOITZIK, Volker; MÜLLER, Manfred; STÄHLER, Cord Friedrich and STÄHLER, Peer Friedrich. Validation of a novel, fully integrated and flexible microarray benchtop facility for gene expression profiling. Nucleic Acids Research, December 2003, vol. 31, no. 23, p. e151.

BEIER, Markus and HOHEISEL, Jörg D. Production by quantitative photolithographic synthesis of individually quality checked DNA microarrays. Nucleic Acids Research, February 2000, vol. 28, no. 4, p. e11.

BÖHME, Herbert. Regulation of nitrogen fixation in heterocyst-forming cyanobacteria. Trends in Plant Science, September 1998, vol. 3, no. 9, p. 346-351.

DIXON, Ray and KAHN, Daniel. Genetic regulation of biological nitrogen fixation. Nature Reviews Microbiology, August 2004, vol. 2, no. 8, p. 621-631. 
DUTTA, Debajyoti; DE, Debojyoti; CHAUDHURI, Surabhi and BHATTACHARYA, Sanjoy K. Hydrogen production by Cyanobacteria. Microbial Cell Factories, December 2005, vol. 4, no. 1, p. 36.

EBERWINE, James; YEH, Hermes; MIYASHIRO, Kevin; CAO, Yanxiang; NAIR, Suresh; FINNELL, Richard; ZETTEL, Martha and COLEMAN, Paul. Analysis of gene expression in single live neurons. Proceedings of the National Academy of Sciences of the United States of America, April 1992, vol. 89, no. 7, p. 3010-3014.

EHIRA, Shigeki; OHMORI, Masayuki and SATO, Naoki. Identification of Low-temperature-regulated ORFs in the cyanobacterium Anabaena sp. strain PCC 7120: distinguishing the effects of low temperature from the effects of photosystem II excitation pressure. Plant and Cell Physiology, August 2005, vol. 46, no. 8, p. 1237-1245.

EHIRA, Shigeki and OHMORI, Masayuki. NrrA, a nitrogen-responsive response regulator facilitates heterocyst development in the cyanobacterium Anabaena sp. strain PCC 7120. Molecular Microbiology, March 2006, vol. 59, no. 6 , p. 1692-1703.

FAY, Peter. Oxygen relations of nitrogen fixation in cyanobacteria. Microbiological Reviews, June 1992, vol. 56, no. 2, p. 340-373.

GOLDEN, James W. and YOON, Ho-Sung. Heterocyst formation in Anabaena. Current Opinions in Microbiology, December 1998, vol. 1, no. 6, p. 623-629.

GÜIMIL, Ramon; BEIER, Markus; SCHEFFLER, Matthias; REBSCHER, Hans; FUNK, Jörg-Michael; WIXMERTEN, Anke; BAUM, Michael; HERMANN, Carsten; TAHEDL, Harald; MOSCHEL, Erich; OBERMEIER, Frank; SOMMER, I.; BÜCHNER, Daniel; VIEHWEGER, R.; BURGMAIER, Josef; STÄHLER, Cord Friedrich; MÜLLER, Manfred and STÄHLER, Peer Friedrich. Geniom ${ }^{\circledR}$ technology - the benchtop array facility. Nucleosides, Nucleotides and Nucleic Acids, October 2003, vol. 22, no. 5-8, p. 1721-1723.

HAPPE, Thomas; SCHÜTZ, Kathrin and BÖHME, Herbert. Transcriptional and mutational analysis of the uptake hydrogenase of the filamentous cyanobacterium Anabaena variabilis ATCC 29413. Journal of Bacteriology, March 2000, vol. 182, no. 6, p. 1624-1631.

HASAN, Ahmad; STENGELE, Klaus-Peter; GIEGRICH, Heiner; CORNWELL, Paul; ISHAM, Kenneth R.; SACHLEBEN, Richard A.; PFLEIDERER, Wolfgang and FOOTE, Robert S. Photolabile protecting groups for nucleotides: synthesis and photodeprotection rates. Tetrahedron, March 1997, vol. 53, no. 12, p. 4247-4264.
HASELKORN, Robert and BUIKEMA, William J. Nitrogen fixation in cyanobacteria. In: STACEY, Gary; BURRIS, Robert H. and EVANS, Harold J. eds. Biological Nitrogen Fixation. Chapman \& Hall, Inc. NY, USA, 1992, p. 166-190.

HEDDAD, Mounia and ADAMSKA, Iwona. The evolution of light stress proteins in photosynthetic organisms. Comparative and Functional Genomics, December 2002, vol. 3, no. 6, p. 504-510.

HERRERO, Antonia; MURO-PASTOR, Alicia M. and FLORES, Enrique. Nitrogen control in cyanobacteria. Journal of Bacteriology, January 2001, vol. 183, no. 2, p. 411-425.

HERRERO, Antonia; MURO-PASTOR, Alicia M.; VALLADARES, Ana and FLORES, Enrique. Cellular differentiation and the NtcA transcription factor in filamentous cyanobacteria. FEMS Microbiology Reviews, October 2004, vol. 28, no. 4, p. 469-487.

HIGO, Akiyoshi; KATOH, Hiroshi; OHMORI, Kazuko; IKEUCHI, Masahiko and OHMORI, Masayuki. The role of a gene cluster for trehalose metabolism in dehydration tolerance of the filamentous cyanobacterium Anabaena sp. PCC 7120. Microbiology, April 2006, vol. 152, no. 4, p. 979-987.

HOFACKER, Ivo L.; FONTANA, Walter; STADLER, Peter F.; BONHOEFFER, L. Sebastian; TACKER, Manfred and SCHUSTER, Peter. Fast folding and comparison of RNA secondary structures. Monatshefte für Chemie, February 1994, vol. 125, no. 2, p. 167-188.

IMASHIMIZU, Masahiko; YOSHIMURA, Hidehisa; KATOH, Hiroshi; EHIRA, Shigeki and OHMORI, Masayuki. $\mathrm{NaCl}$ enhances cellular cAMP and upregulates genes related to heterocyst development in the cyanobacterium, Anabaena sp. strain PCC 7120. FEMS Microbiology Letters, November 2005, vol. 252, no. 1, p. 97-103.

JONES, Kathryn M. and HASELKORN, Robert. Newly identified cytochrome $c$ oxidase operon in the nitrogenfixing cyanobacterium Anabaena sp. strain PCC 7120 specifically induced in heterocysts. Journal of Bacteriology, May 2002, vol. 184, no. 9, p. 2491-2499.

KANEKO, Takakazu; NAKAMURA, Yasukazu; WOLK, C. Peter; KURITZ, Tanya; SASAMOTO, Shigemi; WATANABE, Akiko; IRIGUCHI, Mayumi; ISHIKAWA, Atsuko; KAWASHIMA, Kumiko; KIMURA, Takaharu; KISHIDA, Yoshie; KOHARA, Mitsuyo; MATSUMOTO, Midori; MATSUNO, Ai; MURAKI, Akiko; NAKAZAKI, Naomi; SHIMPO, Sayaka; SUGIMOTO, Masako; 
TAKAZAWA, Masaki; YAMADA, Manabu; YASUDA, Miho and TABATA, Satoshi. Complete genomic sequence of the filamentous nitrogen-fixing cyanobacterium Anabaena sp. strain PCC 7120. DNA Research, October 2001, vol. 8, no. 5, p. 205-213.

KAWASHIMA, Shuichi; KATAYAMA, Toshiaki; SATO, Yoko and KANEHISA, Minoru. KEGG API: A web service using SOAP/WSDL to access the KEGG system. Genome Informatics, 2003, vol. 14, p. 673-674.

KUO, Winston Patrick; JENSSEN, Tor-Kristian; BUTTE, Atul J.; OHNO-MACHADO, Lucila and KOHANE, Isaac S. Analysis of matched mRNA measurements from two different microarray technologies. Bioinformatics, March 2002, vol. 18 , no. 3, p. 405-412.

LECHNO-YOSSEF, Sigal; FAN, Qing; EHIRA, Shigeki; SATO, Naoki and WOLK, C. Peter. Mutations in four regulatory genes have interrelated effects on heterocyst maturation in Anabaena sp. strain PCC 7120. Journal of Bacteriology, November 2006, vol. 188, no. 21, p. $7387-$ 7395.

LOCKHART, David J.; DONG, Helin; BYRNE, Michael C.; FOLLETTIE, Maximillian T.; GALLO, Michael V.; CHEE, Mark S.; MITTMANN, Michael; WANG, Chunwei; KOBAYASHI, Michiko; NORTON, Heidi and BROWN, Eugene L. Expression monitoring by hybridization to high-density oligonucleotide arrays. Nature Biotechnology, December 1996, vol. 14, no. 13, p. 16751680.

MANIATIS, Tom; FRITCH, Edward F. and SAMBROOK, Joseph. Synthesis and cloning of cDNA. In: SAMBROOK, Joseph and RUSSELL, David W. Molecular cloning. Cold Spring Harbor Laboratory Press, 1982, p. 212-246.

MARTÍN-FIGUEROA, Eugenio; NAVARRO, Francisco and FLORENCIO, Francisco J. The GS-GOGAT pathway is not operative in the heterocysts. Cloning and expression of $g l s F$ gene from the cyanobacterium Anabaena sp. PCC 7120. FEBS Letters, July 2000, vol. 476, no. 3, p. 282-286.

MASUKAWA, H.; MOCHIMARU, M. and SAKURAI, H. Disruption of the uptake hydrogenase gene, but not of the bidirectional hydrogenase gene, leads to enhanced photobiological hydrogen production by the nitrogen-fixing cyanobacterium Anabaena sp. PCC 7120. Applied Microbiology and Biotechnology, April 2002, vol. 58, no. 5, p. 618-624.

MEEKS, John C. and ELHAI, Jeff. Regulation of cellular differentiation in filamentous cyanobacteria in free-living and plant-associated symbiotic growth states. Microbiology and Molecular Biology Reviews, March 2002, vol. 66, no. 1, p. 94-121.
MONTANÉ, Marie-Hélène and KLOPPSTECH, Klaus. The family of light-harvesting-related proteins (LHCs, ELIPs, HLIPs): was the harvesting of light their primary function? Gene, November 2000, vol. 258, no. 1-2, p. 1-8.

MURO-PASTOR, Alicia M.; VALLADARES, Ana; FLORES, Enrique and HERRERO, Antonia. The hetC gene is a direct target of the NtcA transcriptional regulator in cyanobacterial heterocyst development. Journal of Bacteriology, November 1999, vol. 181, no. 21, p. 66646669.

MURRY, Marcia A. and WOLK, C. Peter. Evidence that the barrier to the penetration of oxygen into heterocysts depends upon two layers of the cell envelope. Archives of Microbiology, May 1989, vol. 151, no. 6, p. 469-474.

ORR, J. and HASELKORN, R. Regulation of glutamine synthetase activity and synthesis in free-living and symbiotic Anabaena spp. Journal of Bacteriology, November 1982, vol. 152, no. 2, p. 626-635.

POZHITKOV, Alex; NOBLE, Peter A.; DOMAZETLOSO, Tomislav; NOLTE, Arne W.; SONNENBERG, Rainer; STAEHLER, Peer; BEIER, Markus and TAUTZ, Diethard. Tests of rRNA hybridization to microarrays suggest that hybridization characteristics of oligonucleotide probes for species discrimination cannot be predicted. Nucleic Acids Research, May 2006, vol. 34, no. 9, p. e66.

PRINCE, Roger C. and KHESHGI, Haroon S. The photobiological production of hydrogen: potential efficiency and effectiveness as a renewable fuel. Critical Reviews in Microbiology, February 2005, vol. 31, no. 1, p. 19-31.

SCHMETTERER, Georg. Cyanobacterial respiration. In: BRYANT, D.A. ed. The Molecular Biology of Cyanobacteria. Kluwer Academic Publisher, NL, 1994, p. 409-435.

SINGH, S.; KATE, B.N. and BANERJEE, U.C. Bioactive compounds from cyanobacteria and microalgae: an overview. Critical Reviews in Biotechnology, July 2005, vol. 25 , no. 3, p. 73-95.

SINGH-GASSON, Sangeet; GREEN, Roland D.; YUE, Yongjian; NELSON, Clark; BLATTNER, Fred; SUSSMAN, Michael R. and CERRINA, Franco. Maskless fabrication of light-directed oligonucleotide microarrays using a digital micromirror array. Nature Biotechnology, October 1999, vol. 17, no. 10, p. 974-978.

STANIER, R.Y.; KUNISAWA, R.; MANDEL, M. and COHEN-BAZIRE, G. Purification and properties of unicellular blue-green algae (order Chroococcales). 
Bacteriological Reviews, June 1971, vol. 35, no. 2, p. 171205.

VALLADARES, Ana; HERRERO, Antonia; PILS, Dietmar; SCHMETTERER, Georg and FLORES, Enrique. Cytochrome c oxidase genes required for nitrogenase activity and diazotrophic growth in Anabaena sp. PCC 7120. Molecular Microbiology, March 2003, vol. 47, no. 5, p. 1239-1249.

VÁZQUEZ-BERMÚDEZ, María Félix; HERRERO, Antonia and FLORES, Enrique. 2-Oxoglutarate increases the binding affinity of the NtcA (nitrogen control) transcription factor for the Synechococcus $g \ln A$ promoter. FEBS Letters, February 2002, vol. 512, no. 1-3, p. 71-74.

VÁZQUEZ-BERMÚDEZ, María Félix; HERRERO, Antonia and FLORES, Enrique. Carbon supply and 2oxoglutarate effects on expression of nitrate reductase and nitrogen-regulated genes in Synechococcus sp. strain PCC 7942. FEMS Microbiology Letters, April 2003, vol. 221, no. 2, p. 155-159.

WOLK, C. Peter. Heterocyst formation in Anabaena. In: BRUN, Yves and SHIMKETS, Lawrence J. eds. Prokaryotic Development. American Society for Microbiology, USA, 2000, p. 83-104.

WÜNSCHIERS, Röbbe and LINDBLAD, Peter. Lightdependent hydrogen metabolism and generation by Cyanobacteria. In: NALVA, Hari Singh ed. Handbook of Photochemistry and Photobiology. American Scientific Publishers, North Lewis Way, CA, USA, 2003, vol. 4, p. 295-328.

ZHOU, Yingyao and ABAGYAN, Ruben. Match-only integral distribution (MOID) algorithm for high-density oligonucleotide array analysis. BMC Bioinformatics, January 2002, vol. 3, p. 3 . 